\title{
TINJAUAN YURIDIS KONSEP COMPACT CITY DALAM MENDUKUNG TATA RUANG KOTA
}

\author{
Juridical Review On Compact City Conception To Support City Spatial Planning
}

\author{
Jamilus \\ Badan Penelitian dan Pengembangan Hukum dan HAM \\ Kementerian Hukum dan Hak Asasi Manusia \\ Jl. HR. Rasuna Said, Kav 4-5 Kuningan Jakarta Selatan 12940 \\ Email: jamilusbphn@ymail.com
}

Naskah diterima: 5 Juni 2017; revisi: 7 Agustus 2017; disetujui: 8 Agustus 2017

\begin{abstract}
Abstrak
Penataan ruang merupakan suatu tahapan dari proses pengembangan wilayah yang terdiri dari perencanaan, pemanfaatan dan pengendalian ruang. Penataan ruang ditujukan untuk mewujudkan masyarakat makmur yang bertempat tinggal di ruang yang nyaman dan lestari. Saat ini pendekatan compact city menjadi alternatif utama untuk penataan ruang di Indonesia. Penelitian ini menggunakan metode yuridis normatif, untuk membahas bagaimana konsep compact city dalam penataan ruang kota yang efektif dan efisien serta kedudukannya dalam hukum yang berlaku saat ini. Jenis data yang digunakan dalam penelitian ini adalah data sekunder dan data primer. Hasil penelitian menunjukkan bahwa konsep penataan ruang yang efektif dan efisien dapat dilakukan melalui compact city yang menekankan pada dimensi 'kepadatan yang tinggi'. Namun demikian hukum penataan ruang di Indonesia belum mendorong pada konsep compact city. Dengan demikian penting untuk diadakan revisi mengenai Undang-Undang Nomor 26 Tahun 2007.
\end{abstract}

Kata Kunci: penataan ruang, compact city, hukum

\begin{abstract}
Spatial arrangement is a stage of regional development process consisting of planning, utilization and control of space. Spatial planning is aimed at realizing a prosperous society that resides in a comfortable and sustainable space. Compact city approach now becomes main alternative for spatial arrangement in Indonesia. This research uses normative juridical method, to discuss how effective and efficient spatial arrangement and how law arranges effective and efficient spatial arrangement. The type of data used in this research is secondary data and primary data. The results showed that the concept of effective and efficient spatial planning can be done through compact city that emphasizes the dimension of 'high density'. However, the law of spatial planning in Indonesia has not enouraged the concept of compact city. It is therefore important to have a revision of Law Number 26 Year 2007.
\end{abstract}

Keywords: spatial arrangement, compact city, law 


\section{A. Pendahuluan}

Penataan ruang merupakan suatu tahapan dari proses pengembangan wilayah yang terdiri dari perencanaan, pemanfaatan dan pengendalian ruang. Penataan ruang ditujukan untuk mewujudkan masyarakat makmur yang bertempat tinggal di ruang yang nyaman dan lestari. Oleh sebab itu, penerapan prinsipprinsip penataan ruang dalam pembangunan perkotaan sangat relevan dalam rangka mewujudkan pembangunan kota yang sistematis dan terintegrasi. Upaya penataan ruang dalam mendukung pembangunan kota akan efektif dan efisien apabila prosesnya dilakukan secara terpadu dengan seluruh pelaku pembangunan (stakeholder) di wilayah setempat.

Ruang yang meliputi ruang darat, ruang laut, dan ruang udara, termasuk ruang di dalam bumi, sebagai tempat manusia dan makhluk lain hidup, melakukan kegiatan, dan memelihara kelangsungan hidupnya, pada dasarnya ketersediaannya tidak tak terbatas. Berkaitan dengan hal tersebut, dan untuk mewujudkan ruang wilayah nasional yang aman, nyaman, produktif, dan berkelanjutan berlandaskan Wawasan Nusantara dan Ketahanan Nasional, Undang-Undang ini mengamanatkan perlunya dilakukan penataan ruang yang dapat mengharmoniskan lingkungan alam dan lingkungan buatan, yang mampu mewujudkan keterpaduan penggunaan sumber daya alam dan sumber daya buatan, serta yang dapat memberikan perlindungan terhadap fungsi ruang dan pencegahan dampak negatif terhadap lingkungan hidup akibat pemanfaatan ruang. Kaidah penataan ruang ini harus dapat diterapkan dan diwujudkan dalam setiap proses perencanaan tata ruang wilayah. ${ }^{1}$
Ruang sebagai sumber daya pada dasarnya tidak mengenal batas wilayah. Namun, untuk mewujudkan ruang wilayah nasional yang aman, nyaman, produktif, dan berkelanjutan berlandaskan Wawasan Nusantara dan Ketahanan Nasional, serta sejalan dengan kebijakan otonomi daerah yang nyata, luas, dan bertanggung jawab, penataan ruang menuntut kejelasan pendekatan dalam proses perencanaannya demi menjaga keselarasan, keserasian, keseimbangan, dan keterpaduan antardaerah, antara pusat dan daerah, antarsektor, dan antarpemangku kepentingan. Dalam Undang-Undang ini, penataan ruang didasarkan pada pendekatan sistem, fungsi utama kawasan, wilayah administratif, kegiatan kawasan, dan nilai strategis kawasan. Penataan ruang dengan pendekatan kegiatan utama kawasan terdiri atas penataan ruang kawasan perkotaan dan penataan ruang kawasan perdesaan. Kawasan perkotaan, menurut besarannya, dapat berbentuk kawasan perkotaan kecil, kawasan perkotaan sedang, kawasan perkotaan besar, kawasan metropolitan, dan kawasan megapolitan. Penataan ruang kawasan metropolitan dan kawasan megapolitan, khususnya kawasan metropolitan yang berupa kawasan perkotaan inti dengan kawasan perkotaan di sekitarnya yang saling memiliki keterkaitan fungsional dan dihubungkan dengan jaringan prasarana wilayah yang terintegrasi, merupakan pedoman untuk keterpaduan perencanaan tata ruang wilayah administrasi di dalam kawasan, dan merupakan alat untuk mengoordinasikan pelaksanaan pembangunan lintas wilayah administratif yang bersangkutan. Penataan ruang kawasan perdesaan diselenggarakan pada kawasan 
perdesaan yang merupakan bagian wilayah kabupaten atau pada kawasan yang secara fungsional berciri perdesaan yang mencakup 2 (dua) atau lebih wilayah kabupaten pada 1 (satu) atau lebih wilayah provinsi. Kawasan perdesaan yang merupakan bagian wilayah kabupaten dapat berupa kawasan agropolitan. ${ }^{2}$

Kota besar di dunia banyak mengalami permasalahan tata ruang, tidak saja karena kota sejak awal telah dibangun dan bertumbuh secara alami, akan tetapi kota mengalami pertumbuhan lebih pesat, yang biasanya selalu lebih cepat dari konsep tata ruang yang diundangkan karena cepatnya laju pembangunan di perkotaan. Jumlah penduduk yang bertambah setiap tahunnya akan berakibat pada padatnya penduduk di suatu wilayah yang akan berimbas pada meningkatnya kebutuhan tempat tinggal. ${ }^{3}$

Dengan bertambahnya jumlah penduduk perkotaan, negara-negara di dunia akan menghadapi sejumlah tantangan di dalam penyediaan kebutuhan penduduknya, termasuk kebutuhan terhadap perumahan, infrastruktur, transportasi, energi, pelayanan kesehatan dan pendidikan, dan lapangan pekerjaan. Kebutuhan akan ruang di perkotaan tentunya juga akan mengalami peningkatan. Di negara maju, fakta ini telah mendorong munculnya sejumlah konsep pembangunan perkotaan yang menekankan pada efisiensi penggunaan ruang dan energi di perkotaan.

Di antara konsep-konsep yang berkembang dan telah banyak didiskusikan, bahkan diimplementasikan adalah konsep compact city.
Konsep ini menekankan pada morfologi kota yang kompak, dengan mendorong guna lahan campuran (mixeduse) di area perkotaan yang didukung oleh sistem transportasi yang handal.

Berdasarkan uraian di atas, maka fokus penelitian adalah bagaimana konsep compact city dalam penataan ruang kota yang efektif dan efisien serta kedudukannya dalam hukum yang berlaku saat ini.

\section{B. Metode Penelitian}

Penelitian ini menggunakan pendekatan yuridis normatif, dengan demikian jenis data yang digunakan dalam penelitian ini adalah data sekunder dan data primer. Data sekunder berupa buku dan bahan pustaka lainnya seperti, karya ilmiah berupa jurnal, skripsi, tesis, dan disertasi, sementara data primer berupa UUD 1945, Undang-Undang Nomor 26 Tahun 2007 dan peraturan perundang-undangan lainnya. Sifat penelitian ini adalah deskriptif analitik yang ditujukan untukmengungkap suatu masalahatau keadaan atau peristiwa sebagaimana adanya sehingga dapat mengungkapkan fakta yang sebenarnya. ${ }^{4}$ Semua data tersebut dipelajari dengan seksama lalu disajikan dalam bentuk uraian, kemudian data tersebut dianalisis secara kualitatif untuk menjawab permasalahan dalam penelitian yang pada akhirnya menghasilkan kesimpulan dan saran.

Ibid.

John R. Logan and Todd Swanstrom, Beyond the City Limits (Philadelphia: Temple University Press, 1990), hlm. 175.

4 Hadari Nawawi, Metode Penelitian Sosial (Yogyakarta: Gajahmada Press, 1993), hlm, 31. 


\section{Pembahasan}

\section{Compact City dalam Penataan Ruang Kota yang Efektif dan Efisien}

Definisi compact city menurut Jenk-s Burton dan William ${ }^{5}$ dalam tulisannya menekankan pada dimensi 'kepadatan yang tinggi'. Pendekatan compact city adalah meningkatkan kawasan terbangun dan kepadatan penduduk permukiman, mengintensifkan aktifitas ekonomi, sosial dan budaya perkotaan, dan memanipulasi ukuran kota, bentuk dan struktur perkotaan serta sistem permukiman dalam rangka mencapai manfaat keberlanjutan lingkungan, sosial, dan global, yang diperoleh dari pemusatan fungsi-fungsi perkotaan. ${ }^{6}$

Meskipun dalam konsep operasionalnya sangat beragam, dewasa ini di dunia strategi 'kota kompak' (compact city strategy) telah dipandang sebagai alternatif utama ide pengimplementasian pembangunan berkelanjutan dalam sebuah kota. Sebagai akibatnya, ide ini diadopsi oleh banyak kota di dunia, utamanya di negaranegara maju. Kecenderungan pengadopsian ide ini, di samping membawa efek positif pada wacana pembangunan berkelanjutan, tetapi banyak pula yang diterapkan apa adanya tanpa mempertimbangkan permasalahan kota yang ada dan kekhasan sebuah kota. ${ }^{7}$ Pengertian Tata Ruang menurut Undang-Undang Republik Indonesia ${ }^{8}$ adalah wujud struktur ruang dan pola ruang. Sedangkan pengertian kota, ditinjau dari segi geografis menurut Bintarto, ${ }^{9}$ kota dapat diartikan suatu sistem jaringan kehidupan manusia, ditandai dengan kepadatan penduduk yang tinggi dan diwarnai dengan strata sosial ekonomi yang heterogen dan coraknya yang materialistis. Atau dapat pula diartikan sebagai bentang budaya yang ditimbulkan oleh unsurunsur alam dan non alami dengan gejala-gejala pemusatan penduduk yang cukup besar dengan corak kehidupan yang bersifat heterogen dan materialistis dibandingkan dengan daerah di bawahnya. Kawasan perkotaan adalah kawasan yang mempunyai kegiatan utama bukan pertanian dengan susunan fungsi kawasan sebagai tempat pemukiman perkotaan, pemusatan dan distribusi pelayanan jasa pemerintahan, pelayanan sosial dan kegiatan ekonomi. ${ }^{10}$

Beberapa negara telah menerapkan kebijakan Kota Kompak dalam pembangunan kotanya, di antaranya: ${ }^{11}$ Pertama, Australia. Pemerintah Australia telah merilis kebijakan nasional perkotaan Our Cities, Our Future - A National Urban Policy for a Productive, Sustainable, and Liveable Future. Kebijakan ini

5 Mike Jenks, Elizabeth Burton and Katie Williams, The Compact City: A Sustainable Urban Form? (UK: E \& FN Spon, 2005), hlm. 4.

$6 \quad$ Mike Jenks and Rod Burgess, Compact Cities: Sustainable Urban Forms for Developing Countries (London: Spon Press, 2004), hlm. 1.

7 Roychansyah, M. Sani, Paradigma Kota Kompak: Solusi Masa Depan Tata Ruang Kota?, Inovasi Online, Edisi Vol.7/ XVIII/Juni 2006.

8 Pasal 1 ayat 2 Undang-Undang Nomor 26 Tahun 2007 (Lembaran Negara Republik Indonesia Tahun 2007 Nomor 68).

$9 \quad$ R. Bintarto, Interaksi Desa - Kota dan Permasalahannya (Jakarta: Ghalia Indonesia, 1989), hlm. 5.

10 Pasal 1 angka 10 Undang-Undang Nomor 26 Tahun 2007 (Lembaran Negara Republik Indonesia Tahun 2007 Nomor 68).

11 Tim Peneliti Program Studi Perencanaan Wilayah dan Kota, Penangangan Masalah Permukiman Perkotaan melalui Penerapan Konsep Kota Kompak Compact City) dan Transit-Oriented Development (Yogyakarta: UGM, tt), hlm. 10-11. 
menetapkan 14 target bagi kota-kota besar di Australia, di antaranya adalah mengintegrasikan guna lahan dan infrastruktur, menjaga keseimbangan alam dan lingkungan terbangun, dan meningkatkan aksesibilitas dan mengurangi ketergantungan pada kendaraan pribadi. Kedua, Republik Ceko. Pada tahun 2010, Pemerintah Republik Ceko mengeluarkan kebijakan nasional perkotaan, the National Principles of Urban Policy, untuk mendorong permukiman yang kompak dengan guna lahan campuran. Ketiga, Perancis. Perancis telah memperbaharui pendekatan perencanaan kotanya untuk mengikutsertakan konsep Kota Kompak dengan mengeluarkan the Grenelle de l'Environnement pada tahun 2007. Kebijakan ini memungkinkan pemerintah kota untuk menetapkan kepadatan minimum di area perkotaan, dan memberikan insentif dan disinsentif untuk menerapkan kepadatan yang diinginkan. Keempat, Jepang. Pemerintah Jepang telah memasukkan konsep Kota Kompak sebagai prioritas utama dalam kebijakan perkotaannya. Konsep Kota Kompak juga didorong sebagai alat untuk menciptakan kota dan wilayah dengan kadar gas karbon yang rendah dalam rangka mencapai target Kyoto Protocol. Kelima, Korea. Pada tahun 2011, konsep Kota Kompak secara eksplisit telah dimasukkan ke dalam strategi perkotaan the National Comprehensive Development Plan.

Di Indonesia, konsep penataan ruang melalui compact city merupakan political will $^{12}$ Pemerintah yang telah mencanangkan pembangunan nasional dilaksanakan secara terencana, komprehenshif, terpadu, terarah, bertahap, dan berkelanjutan dengan mengembangkan tata ruang dalam suatu tata lingkungan yang dinamis serta tetap memelihara kelestarian lingkungan hidup. Pembangunan perkotaan, merupakan bagian dari pembangunan nasional, harus berlandaskan keseimbangan antara berbagai kepentingan, yaitu keseimbangan, keserasian, dan keselarasan antara kepentingan dunia dan akhirat, materil dan spiritual, jiwa dan raga serta individu dan masyarakat.

Dalam perspektif ekonomi, kota sebagai pusat perekonomian ${ }^{13}$ memiliki peran yang sangat besar bagi pembangunan, dimana konstribusinya terhadap pemenuhan kebutuhan hidup warganya melahirkan berbagai permasalahan. Jumlah penduduk yang terus bertambah dan dikaitkan dengan implikasinya pada ruang kota, bagi para pakar dan pemerhati lingkungan sangatlah menakutkan. Apalagi ada banyak kejadian terutama di negara berkembang, kota-kota tersebut berkembang tanpa pengendalian. Jumlah penduduk terus bertambah, ruang kota semakin padat dan berkualitas rendah, lalu lintas semrawut, penghijauan sangat kurang, terjadi banjir dan sebagainya.

Pada negara berkembang, ${ }^{14}$ kondisi kotakotanya semakin hari semakin terpuruk. Meskipun, ada gejala ekonomi kota meningkat, padahal di balik itu tingkat stres warga sangatlah tinggi, jumlah orang yang sakit terus saja bertambah, jumlah penduduk dengan kualitas tinggi terus menurun, dan pada akhirnya, kota yang katanya mengalami kemajuan ekonomi

\footnotetext{
12 Periksa John R. Logan and Todd Swanstrom, Beyond the City Limits (Philadelphia: Temple University Press, 1990), hlm. 86.

13 Ibid., hlm. 119.

14 Periksa Robert B. Potter. Urbanisation and Planning in the 3rd World (London: Routledge, 1985), hlm. 4.
} 
itu mengalami kemunduran dalam berbagai hal, ${ }^{15}$ dengan compact city dapat meningkatkan kawasan terbangun dan kepadatan penduduk permukiman, mengintensifkan aktifitas ekonomi, sosial dan budaya perkotaan, dan memanipulasi ukuran kota, bentuk dan struktur perkotaan serta sistem permukiman dalam rangka mencapai manfaat keberlanjutan lingkungan, sosial, dan global, yang diperoleh dari pemusatan fungsi-fungsi perkotaan

Selain akan terjadi kepadatan dan ketidakteraturan bangunan, akan berdampak buruk juga pada sisi lainnya, antara lain, ${ }^{16}$ (1) kepadatan bangunan dengan tata letak yang tidak teratur, (2) tidak adanya ruang terbuka hijau sebagai daerah resapan hujan dan pengurang polusi udara, (3) akses jalan yang sulit dilewati oleh kendaraan besar (mobil) pada pemukiman padat penduduk, (4) kecilnya jalan akses menuju daerah tertentu karena banyak dijadikan pemukiman, (5) akses untuk mendapatkan air bersih dan air minum sulit didapat, (6) tidak adanya drainase yang baik dapat menyebabkan banjir pada saat musim penghujan, (7) kepadatan penduduk membuat banyak sampah rumah tangga menumpuk, (8) banyak penyakit yang timbul karena lingkungan yang tidak bersih, (9) buruknya instalasi kelistrikan di daerah tersebut, (10) banyaknya kejadian kebakaran yang terjadi di permukiman padat karena hubungan arus pendek listrik, (11) banyaknya sungai atau drainase yang tercemar oleh limbah rumah tangga.

Dari uraian di atas dapat dipahami bahwa akan banyak dampak buruk yang ditimbulkan akibat tidak adanya perencanaan penataan dalam sebuah wilayah permukiman, terlebih lagi pada permukiman padat dengan jumlah penduduk yang padat pula. Dalam hal ini perlu adanya intervensi dari pemerintah untuk melakukan penerapan compact city dalam setiap pembangunan di wilayahnya. Meskipun pada umumnya kota telah dilengkapi dengan Rencana Tata Ruang Wilayah (RTRW), bahkan dengan perencanaan yang lebih detail dalam bentuk Rencana Detail Tata Ruang Kota (RDTR) serta perencanaannya yang kedalamannya sudah sampai pada Rencana Tata Bangunan dan Lingkungan (RTBL) dan Zoning Regulation. Namun, pengalaman membuktikan bahwa rencana yang telah diundangkan tidak dijadikan sebagai rujukan dalam pemanfaatan ruang berupa pembangunan sarana gedung, perumahan maupun pembangunan sarana dan prasana kota lainnya.

Konsep compact city sebenarnya sudah digagas oleh Budiarjo, ${ }^{17}$ bahwa penyusunan rencana tata ruang harus dilandasi pemikiran perspektif menuju keadaan pada masa depan yang didambakan, bertitik tolak dari data, informasi, ilmu pengetahuan dan teknlogi yang dapat dipakai, serta memperhatikan keragaman wawasan kegiatan tiap sektor. Konsep compact city juga harus dapat menjaga kelestarian lingkungan hidup, maka kebijaksanaan pokok yang nanti dapat ditempuh yakni dengan jalan sebagai berikut: ${ }^{18}$ Pertama, mengembangkan kelembagaan melalui penetapan organisasi pengelolaan yang mantap, dengan rincian tugas, wewenang dan tanggung jawab yang 
jelas. Kedua, meningkatkan kemampuan aparatur yang dapat mendukung kegiatan penataan ruang dan penataan pertanahan demi menjaga kelestarian lingkungan hidup. Ketiga, memasyarakatkan penataan ruang dan penataan pertanahan demi menjaga kelesatarianlingkunganhidupkepadamasyarakat dan dunia usaha serta unsur lain. Keempat, memantapkan pemanfaatan rencana tata ruang sebagai acuan bagi pembangunan daerah dengan perhatian khusus pada kawasan cepat berkembang dan kawasan andalan, serta kawasan strategis. Kelima, memantapkan pengendalian pemanfaatan ruang termasuk pengamanan terhadap kawasan yang memiliki aset penting bagi pemerintah daerah. Keenam, meningkatkan sistem informasi, pemantauan dan evaluasi dalam penataan ruang dan penataan pertanahan demi menjaga kelestarian lingkungan hidup.

Pengaturan compact city dilaksanakan secara bersama-sama, terpadu dan menyeluruh dalam upaya mencapai tujuan pembangunan, penataan ruang diselenggarakan berdasarkan asas (1) keterpaduan, (2) keserasian, keselarasan, dan kesinambungan, (3) keberlanjutan, (4) keberdayagunaan dan keberhasilgunaan, (5) keterbukaan, (6) kebersamaan dan kemitraan, (7) perlindungan kepentingan umum, (8) kepastian hukum dan keadilan, (9) akuntabilitas. ${ }^{19}$

Melihat kondisi tersebut di atas, pembangunan di Indonesia khususnya di beberapa wilayah perkotaan wajib memilikisuatu konsep perencanaan tata ruang, yang disebut dengan Master Plan yang berdasarkan konsep compact city, di mana konsep tersebut sebagai arahan dan pedoman dalam melaksanakan pembangunan, sehingga masalah-masalah yang akan timbul yang diakibatkan dari hasil pembangunan akan diminimalisir.

Pentingnya Penataan Ruang dengan konsep compact city, antara lain, ${ }^{20}$ pertama, untuk meningkatkan sistem penyusunan rencana tata ruang, memantapkan pengelolaan pemanfaatan ruang dan memantapkan pengendalian pemanfaatan ruang terutama untuk mempertahankan pemanfaatan fungsi lahan irigasi teknis dan kawasan-kawasan lindung; meningkatkan kapasitas kelembagaan dan organisasi penataan ruang di daerah, baik aparat pemerintah daerah, lembaga legislatif, dan yudikatif maupun lembaga-lembaga dalam masyarakat agar rencana tata ruang ditaati oleh semua pihak secara konsisten.

Kedua, meningkatkan asas manfaat berbagai sumber daya yang ada dalam lingkungan seperti meningkatkan fungsi perlindungan terhadap tanah, hutan, air, flora, fungsi industri, fungsi pertanian, fungsi pemukiman dan fungsi lain. Kesalahan tata ruang lingkungan dapat menimbulkan dampak pada udara dan iklim, perairan, lahan dan lain-lain yang akan berakibat fatal bagi kelangsungan hidup manusia dan makhluk hidup lainnya.

Ketiga, sesuai dengan Undang-Undang Nomor 26 Tahun 2007 tentang Penataan Ruang di antaranya adalah untuk memperkokoh Ketahanan Nasional berdasarkan Wawasan Nusantara dan sejalan dengan kebijakan otonomi daerah yang memberikan kewenangan semakin besar kepada pemerintah daerah dalam penyelenggaraan penataan ruang,

19 Sesuai amanah Bab II Pasal 2 Undang-Undang Nomor 26 Tahun 2007 tentang Penataan Ruang.

20 Bandingkan dengan Vanessa Watson, Change and Continuity in Spatial Planning Metropolitan Planning in Cape Town Under Political Transition (London: Routledge, 2002), hlm. 141. 
maka kewenangan tersebut perlu diatur demi menjaga keserasian dan keterpaduan antar daerah dan antara pusat dan daerah agar tidak menimbulkan kesenjangan antardaerah;

Bila dilaksanakan secara komprehenshif dan konsekuen, maka penataan ruang dengan konsep compact city dapat menjadi alat yang efektif untuk mencegah kerusakan lingkungan dan berbagai bencana lingkungan seperti banjir dan longsor. Pemanfaatan ruang yang sesuai dengan rencana tata ruang dan mengindahkan kondisi lingkungan dapat menghindari permasalahan lingkungan di masa mendatang.

\section{Kedudukan Compact City dalam Hukum Penataan Ruang}

Indonesia adalah negara kepulauan terbesar di dunia yang terdiri dari 13.466 pulau, $^{21}$ nama alternatif yang biasa dipakai adalah Nusantara. ${ }^{22}$ Dengan populasi lebih dari 263.846.946 juta jiwa pada tahun 2016, ${ }^{23}$ Indonesia menduduki urutan keempat terpadat penduduknya setelah Tiongkok, India dan Amerika Serikat. ${ }^{24}$ Konsep Penataan Ruang secara yuridis bahwa penataan ruang diklasifikasikan berdasarkan sistem, fungsi utama kawasan, wilayah administratif, kegiatan kawasan, dan nilai strategis kawasan. ${ }^{25}$ Wilayah negara Indonesia terdiri dari wilayah nasional sebagai suatu kesatuan wilayah provinsi dan wilayah kabupaten/kota yang masing-masing merupakan sub-sistem ruang menurut batasan administrasi. Dapat digambarkan bahwa di dalam sub-sistem tersebut terdapat sumber daya manusia dengan berbagai macam kegiatan pemanfaatan sumber daya alam dengan sumber daya buatan, dengan tingkat pemanfaatan ruang yang berbeda-beda. Aktivitas pembangunan tersebut tentu saja memerlukan lahan dan ruang sebagai tempat untuk menampung kegiatan pembangunan dimaksud. Penggunaan lahan oleh setiap aktivitas pembangunan sedikitnya akan mengubah rona awal lingkungan menjadi rona lingkungan baru, sehingga terjadi perubahan kesinambungan lingkungan, yang kalau tidak dilakukan penggarapan secara cermat dan bijaksana, akan terjadi kemerosotan kualitas lingkungan, merusak dan bahkan memusnahkan kehidupan habitat tertentu dalam ekosistem bersangkutan. Selanjutnya ditegaskan sebagai berikut: ${ }^{26}$

a. Penataan ruang berdasarkan sistem terdiri atas sistem wilayah dan sistem internal perkotaan.

b. Penataan ruang berdasarkan fungsi utama kawasan terdiri dari kawasan lindung dan kawasan budi daya.

c. Penataan ruang berdasarkan wilayah administrasi terdiri atas penataan ruang wilayah nasional, penataaan ruang wilayah provinsi, dan penataan ruang wilayah kabupaten/kota.

d. Penataan ruang berdasarkan kegiatan kawasan terdiri atas penataan ruang

21 Metrotvnews. Jum'at, 18 Oktober 2013.

22 Justus M. van der Kroef The Term Indonesia: Its Origin and Usage. Journal of the American Oriental Society 71(3), 1951, hlm. 166-171.

23 Badan Pusat Statistik, Proyeksi Penduduki Indonesia 2010-3035, (Jakarta: BPPN, BPS, 2013), hlm. 25.

24 Ibid.

25 Pasal 4 Undang-Undang Nomor 26 Tahun 2007 Undang-Undang Nomor 26 Tahun 2007 (Lembaran Negara Republik Indonesia Tahun 2007 Nomor 68).

26 Ibid., Pasal 5. 
kawasan perkotaan, dan penataan ruang kawasan perdesaan.

e. Penataan ruang berdasarkan nilai strategis kawasan terdiri atas penataan ruang kawasan strategis nasional, penatan ruang kawasan strategis provinsi, dan penataan ruang kawasan strategis kabupaten/kota.

Hukum penataan ruang dengan konsep compact city yang efektif dan efisien di Indonesia harus memperhatikan fenomena urban sprawl dan liberalisasi pasar tanah telah menimbulkan sejumlah permasalahan perkotaan, di antaranya: pertama kemacetan. Dengan bertambahnya jumlah penduduk di perkotaan dan semakin meluasnya jangkauan perkotaan, kebutuhan akan sarana transportasi untuk melayani pergerakan barang dan jasa dari daerah pinggiran menuju pusat kota menjadi meningkat. Kedua, berkurangnya kenyamanan kawasan perkotaan. Tingkat kenyamanan kawasan perkotaan dirasakan semakin berkurang. Bertambahnya jumlah penggunaan kendaraan bermotor, tumbuhnya perumahanperumahan baru akibat pertumbuhan jumlah penduduk, dan berkurangnya penyediaan ruang terbuka hijau di perkotaan telah berkontribusi pada menurunnya kualitas hidup di perkotaan. Munculnya kebisingan dan polusi, berkurangnya ruang publik, dan marjinalisasi pejalan kaki juga menjadi indikator menurunnya kualitas lingkungan perkotaan. Ketiga, inefisiensi penggunaan energi. Dengan meningkatnya penggunaan kendaraan bermotor untuk memfasilitasi pergerakan dari kawasan pinggiran ke pusat kota, tingkat penggunaan bahan bakar tentunya juga akan meningkat. Selain itu, zonazona kegiatan perkotaan yang terpisah-pisah juga menyebabkan bertambahnya jarak tempuh untuk melakukan pergerakan dari satu zona ke zona lainnya. Berkurangnya lahan hijau di perkotaan juga berakibat pada meningkatnya suhu udara di kawasan perkotaan yang dapat memicu peningkatan penggunaan pendingin. Keempat, ketidakadilan akses perumahan. Tidak terkendalinya pasar tanah di perkotaan juga telah menyebabkan ketidakadilan dalam mengakses perumahan. Melihat fenomena perkembangan perkotaan di Indonesia dan permasalahan yang muncul, konsep compact city dapat dilihat sebagai sebuah solusi.

Melalui penerapan konsep compact city, lahan-lahan di perkotaan akan dimanfaatkan seefisien mungkin menjadi permukiman berkepadatan tinggi dengan berbagai macam fungsi perkotaan yang diwadahi pada beberapa pusat kegiatan. Pusat kota akan dibagi menjadi pusat-pusat kecil yang mandiri yang dapat mengakomodasi fungsi wisma, karya, suka, dan marga yang berdekatan, sehingga akan dengan memperpendek jarak tempuh perjalanan dari satu fungsi ke fungsi lainnya. Sementara itu, kotakota satelit di sekitar kota inti akan diintegrasikan dengan simpul-simpul transit pergerakan, seperti kemungkinan pengembangan railbased development. Hal yang sama juga diterapkan pada penentuan pusat-pusat kegiatan baru dengan guna lahan campuran di sekitar simpul transportasi perkotaan.

Peraturan yang berkaitan dengan penataan ruang (kota) modern di Indonesia telah diperhatikan ketika kota Jayakarta (kemudian menjadi Batavia) dikuasai oleh Belanda pada awal abad ke-7, tetapi peraturan tersebut baru dikembangkan secara insentif pada awal abad ke-20. Peraturan pertama yang dapat dicatat disini adalah De Statuen Van 1642 yang dikeluarkan oleh VOC khusus untuk kota Batavia.

Peraturan ini tidak hanya membangun pengaturan jalan, jembatan dan bangunan 
lainnya, tetapi juga merumuskan wewenang dan tanggung jawab pemerintah kota. Pembangunan peraturan kota mulai diperhatikan lagi setelah Pemerintah Hindia Belanda menerbitkan Undang-Undang Desentralisasi pada tahun 1903 yang mengatur pembentukan pemerintah kota dan daerah. Di mana undang-undang ini memberikan hak kepada kota-kota untuk mempunyai pemerintahan, administrasi dan keuangan kota sendiri.

Tugas pemerintahan kota diantaranya adalah pembangunan dan pemeliharaan jalan dan saluran air, pemeriksaan bangunan dan perumahan, perbaikan perumahan dan perluasan kota. Berdasarkan undang-undang ini dibentuklah pemerintahan otonom yang disebut Gemeente, baik di Jawa maupun di luar Jawa. Tak lama kemudian, pada tahun 1905 diterbitkan Localen-Raden Ordonantie, Stb. 1905/191 Tahun 1905 yang antara lain berisi pemberian wewenang pada pemerintahan kota untuk menentukan prasyarat persoalan pembangunan kota.

Karena mengalami beberapa persoalan mengenai pembentukan kota, pada akhirnya pemerintah Hindia Belanda menyadari perlunya perencanaan kota yang menyeluruh. Hal inilah yang memicu dimulainya pengembangan perencanaan kota di Indonesia, meskipun pada saat itu belum ada peraturan pemerintah yang seragam.

Peraturan pembangunan kota tidak dapat dipisahkan dengan usaha-usaha Thomas Karsten, yang dalam kegiatannya dari tahun 1902 sampai dengan 1940 telah menghasilkan dasardasar yang kokoh bagi perkembangan peraturan pembangunan kota yang menyeluruh, antara lain untuk penyusunan rencana umum, rencana detail, dan peraturan bangunan. Laporan Thomas Karsten mengenai pembangunan kota
Hindia Belanda yang diajukan pada kongres desentralisasi pada tahun 1920 tidak hanya berisikan konsep dasar pembangunan kota dan peran pemerintah kota, tetapi juga merupakan petunjuk praktis yang dapat digunakan sebagai pedoman untuk penyusunan berbagai jenis rencana.

Peraturan yang penting bagi perencanaan kota yang disahkan pada tahun 1926 adalah Bijblad, di mana peraturan ini yang menjadi dasar kegiatan perencanaan kota sebelum perang kemerdekaan. Kemudian dilanjutkan pada tahun 1933, kongres desentralisasi di Indonesia meminta pemerintahan Hindia Belanda untuk memusatkan persiapan peraturan perencanaan kota tingkat pusat. Menyusul permintaan ini, dibentuklah suatu Panitia Perencanaan Kota pada tahun 1934 untuk menyiapkan peraturan perencanaan kota sebagai pengganti Bijblad.

Pada tahun 1939 pemerintah Hindia Belanda menyusun RUU Perencanaan Wilayah perkotaan di Jawa yang berisikan persyaratan pembangunan kota untuk mengatur kawasankawasan perumahan, transportasi, tempat kerja dan rekreasi.

Masuknya Jepang ke Indonesia dan adanya perang kemerdekaan Indonesia menyebabkan RUU Perencanaan Wilayah Perkotaan di Jawa baru disahkan pada tahun 1948 dengan nama Stadsvorming Ordonantie, Stb 1948/168 (SVO, atau Ordonansi Pembentukan Kota), yang kemudian diikuti dengan peraturan pelaksanaanya yaitu Stadsvormingverordening, Stb 1949/40 (SVV atau Peraturan Pembentukan Kota).

SVO dan SVV diterbitkan untuk mempercepat pembangunan kembali wilayahwilayah yang hancur akibat peperangan dan pada mulanya hanya diperuntukan bagi 15 kota, yakni Batavia, Tegal, Pekalongan, 
Semarang, Salatiga, Surabaya, Malang, Padang, Palembang, Banjarmasin, Cilacap, Tanggerang, Bekasi, Kebayoran dan Pasar Minggu.

Pesatnya perkembangan kota dan berubahnya karakteristik kota menyebabkan SVO tidak sesuai lagi untuk mengatur penataan ruang di Indonesia, selain hanya diperuntukan bagi 15 kota, ordonansi ini hanya menciptakan dan mengatur kawasan-kawasan elite serta tidak mampu mengikuti perkembangan yang ada. Karena itulah pemerintah Indonesia mengajukan RUU Bina Kota pada tahun 1970 yang dipersiapkan oleh Departemen PUTL.

RUU ini mencakup ketentuan-ketentuan antara lain tahapan pembangunan, pembiayaan pembangunan, peraturan bangunan, dan peremajaan kota. Namun, usulan tersebut tidak pernah disetujui.

Setelah melalui proses yang panjang, akhirnya Indonesia menyusun Undang-Undang Nomor 24 tahun 1992 tentang Penataan Ruang, yang akhirnya undang-undang tersebut disahkan dan berlaku. Namun seiring dengan adanya perubahan terhadap paradigma otonomi daerah melalui ketentuan Undang-Undang Nomor 32 Tahun 2004 tentang Pemerintahan Daerah, maka ketentuan mengenai penataan ruang mengalami perubahan yang ditandai dengan digantinya Undang-Undang Nomor 24 Tahun 1992 tentang Penataan Ruang menjadi Undang-Undang Nomor 26 Tahun 2007 tentang Penataan Ruang.

Beberapa kelemahan Undang-Undang Nomor 26 Tahun 2007 tentang Penataan Ruang antara lain: Pertama, rencana tata ruang wilayah nasional telah disinggung di dalam Undang-Undang Nomor 26 Tahun 2007 tentang Penataan Ruang, akan tetapi pemerintah juga telah mengeluarkan ketentuan tentang rencana tata ruang wilayah nasional di dalam
Peraturan Pemerintah Nomor 26 tahun 2008 Tentang Rencana Tata Ruang Wilayah Nasional. Kedua, peninjauan, Rencana Tata Ruang Wilayah Nasional sebagaimana dimaksud pada Undang-Undang Nomor 26 Tahun 2007 ditinjau kembali 1 (satu) kali dalam 5 (lima) tahun. Namun peninjauan tersebut bisa terjadi lebih dari satu kali jika ada keadaan darurat seperti bencana alam yang terjadi di wilayah tersebut. Ketiga, produk hukum dari Rencana Tata Ruang Wilayah Nasional adalah peraturan pemerintah, salah satunya adalah dikeluarkannya Peraturan Pemerintah Republik Indonesia Nomor 26 Tahun 2008 tentang Rencana Tata Ruang Wilayah Nasional sebagai pelaksanaan ketentuan Pasal 20 ayat (6) Undang-Undang Nomor 26 Tahun 2007 tentang Penataan Ruang.

Undang-Undang Nomor 26 Tahun 2007 tentang Penataan Ruang menjadi pedoman bagi penataan ruang di Indonesia. Penataannya diimplementasikan melalui rencana umum dan rencana rinci. Pertama, rencana umum tata ruang secara berhierarki terdiri atas: a. Rencana Tata Ruang Wilayah Nasional; b. Rencana Tata Ruang Wilayah Provinsi; dan c. Rencana Tata Ruang Wilayah kabupaten dan rencana tata ruang wilayah kota. Kedua, rencana rinci tata ruang terdiri atas: a. rencana tata ruang pulau/ kepulauan dan rencana tata ruang kawasan strategis nasional; b. rencana tata ruang kawasan strategis provinsi; dan c. rencana detail tata ruang kabupaten/kota dan rencana tata ruang kawasan strategis kabupaten/kota.

Namun demikian belum menerapkan konsep compat city terutama pada rencana tata ruang kota, yang belum merinci tentang meningkatkan kawasan terbangun dan kepadatan penduduk permukiman, mengintensifkan aktifitas ekonomi, sosial dan budaya perkotaan, dan memanipulasi ukuran 
kota, bentuk dan struktur perkotaan serta sistem permukiman dalam rangka mencapai manfaat keberlanjutan lingkungan, sosial, dan global, yang diperoleh dari pemusatan fungsifungsi perkotaan. Muatan isi dari Rencana Tata Ruang Wilayah Kota (RTRWKot) menurut Undang-Undang Nomor 26 Tahun 2007 secara mutatis mutandis sama dengan RTRW Kabupaten, dengan ketentuan selain rincian dalam Pasal 26 ayat (1) ditambahkan konsep compact city dengan: a. rencana penyediaan dan pemanfaatan ruang terbuka hijau; $b$. rencana penyediaan dan pemanfaatan ruang terbuka nonhijau; dan c. rencana penyediaan dan pemanfaatan prasarana dan sarana jaringan pejalan kaki, angkutan umum, kegiatan sektor informal, dan ruang evakuasi bencana, yang dibutuhkan untuk menjalankan fungsi wilayah kota sebagai pusat pelayanan sosial ekonomi dan pusat pertumbuhan wilayah.

\section{Penutup}

Berdasarkan pembahasan di atas dapat disimpulkan bahwa konsep penataan ruang yang efektif dan efisien dapat dilakukan melalui compact city. Definisi compact city menekankan pada dimensi 'kepadatan yang tinggi'. Pendekatan compact city adalah meningkatkan kawasan terbangun dan kepadatan penduduk permukiman, mengintensifkan aktifitas ekonomi, sosial dan budaya perkotaan, dan memanipulasi ukuran kota, bentuk dan struktur perkotaan serta sistem permukiman dalam rangka mencapai manfaat keberlanjutan lingkungan, sosial, dan global, yang diperoleh dari pemusatan fungsi-fungsi perkotaan. Namun demikian hukum penataan ruang di Indonesia belum mendorong pada konsep compact city. Dengan demikian penting untuk diadakan revisi mengenai Undang-Undang Nomor 26 Tahun 2007.

\section{Daftar Pustaka}

\section{Buku}

Akib, Muhammad, Charles Jackson, dkk, Hukum Penataan Ruang (Bandar Lampung: Pusat Kajian Konstitusi dan Peraturan Perundang-Undangan Fakultas Hukum Universitas Lampung, 2013).

Bintarto, R. Interaksi Desa - Kota dan Permasalahannya (Jakarta: Ghalia Indonesia, 1989).

Budiarjo, Eko. Tata Ruang Perkotaan di Indonesia (Bandung: PT. Alumni, 2004).

Burian, Jaroslav, Advances in Spatial Planning (Croatia: InTech, 2012).

Hasni, Hukum Penataan Ruang dan Penatagunaan Tanah (Jakarta: PT RajaGrafindo Persada, 2010).

Jenks, Mike, Elizabeth Burton and Katie Williams, The Compact City: A Sustainable Urban Form? (UK: E \& FN Spon, 2005).

Jenks, Mike and Rod Burgess, Compact Cities: Sustainable Urban Forms for Developing Countries (London: Spon Press, 2004).

Logan, John R. and Todd Swanstrom, Beyond the City Limits (Philadelphia: Temple University Press, 1990).

Morphet, Janice, Effective Practice in Spatial Planning (London: Routledge, 2011).

Muljana, BS, Perencanaan Pembangunan Nasional, Proses Penyusunan Rencana Pembangunan Nasional dengan Fokus Repelita V (Jakarta: UIPress, 2001).

Nawawi, Hadari, Metode Penelitian Sosial (Yogyakarta : Gajahmada Press, 1993).

Potter, Robert $\mathrm{B}$, Urbanisation and Planning in the 3rd World (London: Routledge, 1985).

Tim Peneliti Program Studi Perencanaan Wilayah dan Kota, Penanganan Masalah Permukiman Perkotaan melalui Penerapan Konsep Kota Kompak Compact City) dan Transit-Oriented Development (Yogyakarta: UGM, tt).

Watson, Vanessa, Change and Continuity in Spatial Planning Metropolitan planning in Cape Town under political transition (London: Routledge, 2002).

\section{Makalah/Artikel/Laporan/Hasil Penelitian}


Roychansyah, M. Sani, Paradigma Kota Kompak : Solusi Masa Depan Tata Ruang Kota?, Inovasi Online, Edisi Vol.7/XVIII/Juni, 2006.

\section{Peraturan}

Undang-Undang Dasar Negara Republik Indonesia Tahun 1945.
Undang-Undang Nomor 26 Tahun 2007 tentang Penataan Ruang.

Undang-Undang Nomor 32 Tahun 2004 tentang Pemerintahan Daerah.

Peraturan Pemerintah Nomor 26 Tahun 2008 tentang Rencana Tata Ruang Wilayah Nasional. 
"Halaman ini dikosongkan" 